Original Paper http://ajol.info/index.php/ijbcs http://indexmedicus.afro.who.int

\title{
Comparison of different phosphorous adsorption models in acid forest soils of Bityili (Southern - Cameroon) and their relationship with soil properties
}

\author{
Adalbert Adibime ONANA $^{1 *}$, Antoine David MVONDO ZE ${ }^{1}$, Bernard Palmer YERIMA ${ }^{1}$ \\ and Victor AGOUME ${ }^{2}$ \\ ${ }^{1}$ Laboratory of Soil Analysis and Environmental Chemistry (LASAEC), Soil Sciences Department, \\ Faculty of Agronomy and Agricultural Sciences, University of Dschang, Dschang, Cameroon. \\ Po Box : 222, Dschang, Cameroon. \\ ${ }^{2}$ Development and Agricultural Research Institute (DARI), Yaoundé, Cameroon. Po Box : 2067, Yaoundé, \\ Cameroon. \\ *Corresponding author; E-mail: onanaadibime@gmail.com; Tel. (237)652999824
}

\section{ACKNOWLEDGEMENTS}

The authors of this article would like to thank the FOSAS project of the Japanese International Cooperation Agency (JICA) which made this research work possible through the financial support.

\begin{abstract}
This study was designed to compare the phosphorous fixation capacity of three soils series named Tyele, Minkonmingon and Mekoto in the south region of Cameroon and to determine the soil properties that are the main predictors of the $\mathrm{P}$ activity of those soils. Five adsorption equations viz. Linear, Langmuir, Van Huay, Freundlich and Temkin were used to describe $\mathrm{P}$ adsorption processes. The results of the study showed that maximum adsorbed $\mathrm{P}$ of Minkonmingon, Tyele and Mekoto was 936.09, 311.15 and $823.37 \mathrm{mg} \mathrm{kg}^{-1}$ of soils respectively with the mean of $690.20 \mathrm{mg} \mathrm{kg}^{-1}$ of soils. By applying various models, $\mathrm{P}$ adsorption data revealed that for low concentration range, the Freundlich equation show a better fit followed by the Langmuir, Van Huay, Temkin and Linear equations. It can be thus concluded from the adsorption and Spearman correlation analysis that the soil of Minkonmingon has a greater capacity to fix P followed by those of Mekoto and Tyele respectively with silt, exchangeable acidity, free aluminum, potassium and soil organic carbon and $\mathrm{pH} \mathrm{KCl}$ being the main predictors of $\mathrm{P}$ activity in these soils.

(C) 2016 International Formulae Group. All rights reserved.
\end{abstract}

Keywords: Phosphorous fixation, adsorption isotherms, soil characteristics, correlation, acid soils, Cameroon.

\section{INTRODUCTION}

Phosphate adsorption is the process in which the ions are held on the active sites of the soil particle surfaces (Dubus and becquer, 2001). The amount of phosphate adsorbed by soil increases as the amount of phosphate in solution increases and vice versa (Holford, 1989 ; Wild, 1988). Adsorption affects fate of $\mathrm{P}$ source and the availability of phosphate to plants. The phosphate in fertilizers and 
manure is initially quite soluble and available. Adsorbed or precipitated inorganic phosphate undergoes desorption or dissolution reactions when moving from the solid to the solution phase (Barrow, 1978). Adsorption isotherms can conveniently be described as the equilibrium relationships between the amount of adsorbed and dissolved species of phosphate at constant temperature in quantitative terms (Dubus, 1997). Phosphate adsorption isotherms are important criteria to study the interaction of the ions with the oxides and soil, and have been used to measure the adsorption capacity of the soil (Olsen and Watanabe, 1957). Adsorption is usually characterized by fitting the adsorption isotherm and their mathematical description using one or more adsorption equations.

As of today, many researchers have studied and proposed diverse techniques for evaluation of phosphorous status in the soil. Application of isotherms for phosphorous adsorption by soil is among the techniques proposed in recent years for analyzing phosphorous status in soil. Using this method, the following parameters can be estimated: phosphorous concentration in the aqueous phase of soil, energy of phosphorous concentration variations in solution and maximal value of its adsorption by soil, buffer strength of soil against phosphorous concentration variations in solution, and equilibrium states between phosphorous in aqueous and solid phases and their relationship (Onweremadu, 2007).

Phosphorous adsorption isotherms can also help in making phosphorous fertilizers recommendations. Several researchers during early studies in this field realized that adsorption isotherms could be used in various soils for predicting the amount of fertilizer requirements for crops or provided that the required amount of soluble phosphorous in plant was specified. Concentration of this nutritional element in soil solution is closely linked to adsorption processes through soil constituents such as clay minerals, oxides, iron and aluminum hydroxides, and carbonate calcium, organic matter and so on. These relationships can be described by adsorption isotherms among which are Langmuir, Freundlich, two-surface Langmuir, LangmuirFreundlich, Temkin, Toth and Van Huay models (Dubus and becquer, 2001) are more recognized than others. Saleque et al. (2004) used the Langmuir equation for fitting phosphorous adsorption data and obtained statistically significant relations between parameters of this equation and soil properties such as clay percentage, organic carbon and extractible $\mathrm{Fe}$ and $\mathrm{Al}$ contents with dithionatecitrate-bicarbonate.

Moazed et al. (2013) observed that a significant correlation holds between phosphorous adsorption maxima and organic matter, iron oxides and calcium phosphate in a wide range of equilibrium concentrations (2 $150 \mathrm{ppm}$ ). Niang et al. (2002) reported that phosphorous adsorption data could be explained by the Langmuir, Freundlich and Temkin equations in 12 soils but that the Freundlich isotherm better described phosphorous adsorption at high phosphorous concentrations. Antonio et al., (2002) came to the conclusion that iron, manganese and titanium oxides and also phyllosilicates largely affects surface adsorption of phosphate and arsenate. Furthermore, more phosphate compared to arsenate is adsorbed onto sediments of non crystalline aluminum, boehmite, gibbsite, hematite and kaolinite.

Phosphorous is a critical element in natural and agricultural ecosystems throughout the world (Onweremadu, 2007) as its limited availability is often the main constraint for plant growth in highly 
weathered soils of the tropics (Bunemann et al., 2004a). Phosphorous deficiency problems are common in highly weathered Oxisols and Ultisols because of very acidic nature and abundance of $\mathrm{Al}$ and $\mathrm{Fe}$ ions (Saleque et al., 2004), and the situation can be worsened with inappropriate $\mathrm{P}$ management (Saleque et al., 1998). Keeping in view the diversified behavior of phosphorous in acidic soils, based on the above, and to understand the adsorption capacity of the soil, a study was carried out using three acid forest soils series of Bityili (south region of Cameroon) with the objectives to study the adsorption isotherms of these inherent acidic soil, To determine the adsorption model of soils using four (5) important equations (Linear, Freundlich, Langmuir, Tempkin, and Van Huay) which best fits the $\mathrm{P}$ adsorption data and to investigate the correlation between $\mathrm{P}$ adsorbed and some important soil physico-chemical properties.

\section{MATERIALS AND METHODS}

\section{Soil samples and basic analytical methods}

Three acidic forests soils series namely Tyele, Minkonmingon and Mekoto of Bityili (Southern - Cameroon) were selected to study the mechanism of $\mathrm{P}$ adsorption. The soils are mainly sandy-clayed isohyperthermic ustox. There are yellow soils. The research was carried out in March 2014. The study site of Tyele is located at latitude $02.95731^{\circ} \mathrm{N}$ and longitude $11.19166^{\circ} \mathrm{E}$, at an altitude of $593 \mathrm{~m}$ above the sea level. The study site of Minkonmingon is located at latitude $03.0179^{\circ}$ $\mathrm{N}$ and longitude $11.10332^{\circ} \mathrm{E}$, at an altitude of $662 \mathrm{~m}$ above the sea level and that the one of Mekoto is located at latitude $02.84604^{\circ} \mathrm{N}$ and longitude $11.19354^{\circ} \mathrm{E}$, and at an altitude of $608 \mathrm{~m}$ above the sea level (handled global positioning system - GPS) received ("Garmin Ltd", USA). The area has a Guinean type equatorial climate with two distinct seasons, named wet and two dry seasons. Rainfall distribution is bimodal with peaks during the months of July and September. Temperatures are high and vary only slightly during the year. Representative soil samples of surface horizons $(0-20 \mathrm{~cm})$ were collected, air-dried, crush and sieve to pass through a $2-\mathrm{mm}$ sieve and analyzed for various physicochemical parameters prior to adsorption studies.

\section{Laboratory analysis}

Laboratory analyses were carried out using standard methods (Pauwels et al., 1992). Particle size distribution was determined by the Robinson-Köhn pipette method. Soil pH was measured in 1: 2.5 soil to solution ratio in $1 \mathrm{~N} \mathrm{KCl}(\mathrm{pH} \mathrm{KCl})$ and distilled water $(\mathrm{pH}$ $\mathrm{H}_{2} \mathrm{O}$ ). Soil organic carbon (SOC) was estimated by oxidation with potassium dichromate and titration with ferrous sulfate (Walkley and Black, 1934). Amorphous Fe and $\mathrm{Al}$ were determined colorimetrically after their reduction with ammonium oxalate in the dark, while free $\mathrm{Fe}$ and $\mathrm{Al}$ were determined colorimetrically after reduction with dithionate-citrate-bicarbonate (DCB). Available phosphorous was determined by Bray II method (Bray and Kurtz, 1945). Total phosphorous was determined colorimetically after extraction with boiling concentrated nitric acid. Cation exchange capacity (CEC) was determined by percolating $2.5 \mathrm{~g}$ of soil with $100 \mathrm{~mL}$ of $1 \mathrm{~N}$ ammonium acetate buffered at $\mathrm{pH} 7$, removing the excess with ethanol and displacing the absorb $\mathrm{NH}_{4}{ }^{+}$ions with $1 \mathrm{~N} \mathrm{KCl}$, determining the collected $\mathrm{NH}_{4}{ }^{+}$ ions by distillation and titration with $0.01 \mathrm{~N}$ sulfuric acid. Electrical conductivity (EC) was determined in a ratio 1:5 with soil distilled deionized water solution with a WTW model conductimeter. Exchangeable acidity was 
determined by titration with $\mathrm{NaOH}$ after extraction with $1 \mathrm{~N} \mathrm{KCl}$ in the ratio 1:20.

\section{Phosphorous sorption studies}

The phosphate adsorption studies were carried out following the procedure of Rao (1993). One gram of air dried soil accurately weighted and $50 \mathrm{~mL}$ of solution containing $0.5,1,2.5,5,7.5,10,20,30,40,50,60,70$, $80 \mu \mathrm{g} \mathrm{P} \mathrm{mL} L^{-1}$ prepared in $0.01 \mathrm{M}$ calcium chloride $\left(\mathrm{CaCl}_{2}, 2 \mathrm{H}_{2} \mathrm{O}\right)$ were added and shaken for 24 hours at $20{ }^{\circ} \mathrm{C}$ on an end-to-end shaker (Edmund Bühler SM 25 model) at 125 oscillations per minute and centrifuged tube and rotated at $5000 \mathrm{rpm}$ for 30 minutes with a model HRT 20 MM Multifunctional Intelligent Centrifuge. The soil suspensions were filtered through a Whattman II filter paper to get a clear solution. $1 \mathrm{~mL}$ extract of each of the samples and blank were pipetted in $50 \mathrm{~mL}$ test tubes, $2.5 \mathrm{~mL}$ of mixture containing ammonium molybdate and sulfuric acid, $2.5 \mathrm{~mL}$ of ascorbic acid and $14 \mathrm{~mL}$ of distilled water were added and mixed. The test tubes were then put into a water bath at $85^{\circ} \mathrm{C}$ for 10 minutes to enhance color development. After the development of the blue color, the $\mathrm{P}$ concentration was determined colorimetrically at a wavelength of $665 \mathrm{~nm}$ using a Searchtech $722 \mathrm{~N}$ visible spectrophotometer (Kuo, 1996). All soil samples were analyzed in duplicate. Graph presentation of the adsorption isotherms of the three soils series had different curves (Figure 1). Phosphorous adsorption isotherms were determined using the linearized form of the Linear, Langmuir, Freundlich, Temkin and Van Huay equations (Figures 2 and 6), and the relationship of soil properties with $\mathrm{P}$ sorption were obtained.

The $\mathrm{P}$ adsorption data for the soils used in this study were fitted into the different adsorption equations following the equations proposed by Holford et al. (1974), Dubus and Becquer (2001) and Moazed et al. (2010).

The linear form of the Langmuir equation is defined by:

$\mathrm{C} /(\mathrm{x} / \mathrm{m})=1 / \mathrm{K}_{\mathrm{L}} \mathrm{b}_{\mathrm{L}}+\mathrm{C} / \mathrm{b}_{\mathrm{L}}$

where $\mathrm{C}=\mathrm{P}$ concentration in equilibrium solution $\left(\mathrm{mg} \mathrm{L}^{-1}\right), \mathrm{x} / \mathrm{m}=\mathrm{P}$ adsorbed by soil $\left(\mathrm{mg} \mathrm{P} \mathrm{kg}^{-1}\right), \mathrm{b}_{\mathrm{L}}=\mathrm{P}$ adsorption maximum $(\mathrm{mg}$ $\mathrm{kg}^{-1}$ ) and $\mathrm{K}_{\mathrm{L}}=$ constant related to bonding energy of soil to $\mathrm{P}$ (affinity constant) $\left(\mathrm{L} \mathrm{mg}^{-1}\right.$ $\mathrm{P})$.

The Linear equation is defined by:

$\mathrm{Cs}=\mathrm{K} * \mathrm{Cn}$

where $\mathrm{Cs}=$ the $\mathrm{P}$ concentration of the solute on the surface $\left(\mathrm{mg} \mathrm{kg}^{-1}\right), \mathrm{Cn}=$ the concentration of the solute in solution $(\mathrm{mg} \mathrm{P}$ $\mathrm{L}^{-1}$ ) and $\mathrm{K}=$ adsorption constant of the solute to the stationary phase surface $\left(\mathrm{mg} \mathrm{kg}^{-1}\right)$.

The Freundlich equation is defined by:

$\mathrm{Cs}=\mathrm{Kf}^{*} \mathrm{C}^{1 / \mathrm{n}}$

where $\mathrm{Cs}=\mathrm{P}$ concentration in solid phase $(\mathrm{mg}$ $\left.\mathrm{kg}^{-1}\right), \mathrm{C}=\mathrm{P}$ concentration in fluid phase (mg $\left.\mathrm{L}^{-1}\right), \mathrm{Kf}=$ Freundlich adsorption constant $\left(m g \mathrm{~kg}^{-1}\right)$ and $\mathrm{n}=$ Empirical constant related to bonding energy of soil for phosphate.

The Van Huay equation is defined by:

$\mathrm{X} / \mathrm{m}=\mathrm{m}+\mathrm{nC}^{0.5}$

where $\mathrm{C}=\mathrm{P}$ concentration in fluid phase $(\mathrm{mg}$ $\left.\mathrm{L}^{-1}\right), \mathrm{n}=$ Van Huay adsorption coefficient and $\mathrm{m}=$ Van Huay constant parameter.

The Temkin equation is defined by:

$\mathrm{X}=\mathrm{a}+\mathrm{b} \ln \mathrm{C}$

Where $\mathrm{X}=\mathrm{mg}$ of $\mathrm{P}$ adsorbed by the soil (mg $\left.\mathrm{kg}^{-1}\right), \mathrm{b}=$ buffer capacity of Temkin model $\left(\mathrm{mL} \mathrm{g}^{-1}\right), \mathrm{a}=$ Amount of $\mathrm{P}$ adsorbed $\left(\mathrm{mg} \mathrm{kg}^{-1}\right)$.

\section{Statistical analysis}

Correlation and regression analysis were performed to relate some soil properties to P-sorption characteristics using R ( $\mathrm{R}$ Development Core Team, 2007). 


\section{RESULTS}

Soil properties are shown on Table 1 and phosphorous adsorption characteristics are shown in Tables 2 and 3, indicating variabilities in the $\mathrm{P}$-adsorption characteristics of the soils studied. Table 4 shows the regression equation and $R^{2}$ values of the soil series. Simple correlation results between $P$ adsorption characteristics and some soil properties are shown (Table 5). All the soils series were acidic in nature $(\mathrm{pH}, 4.5-5.2)$. Texture of the soil of Minkonmingon was Clay and soil of Tyele was Clay loam while soil of Mekoto was silty clay loam. The electrical conductivity and the sum of exchangeable bases of the selected soils were low. The organic matter contents of the soils were medium with values between 20 and 40 $\mathrm{g} \mathrm{kg}^{-1}$. The available P (Bray II) was also medium. The free oxides (iron and aluminum) contents of these soils were higher than these amorphous oxides counterparts.

The phosphate adsorption isotherms of the three soil series used in the study were determined by plotting the equilibrium concentration of phosphate (C) against the amount of phosphate adsorbed (X). The adsorption isotherm of the three soil series shows that all the three soil series exhibited different curves. From the amount of $P$ adsorbed by each of the three soil series, it is evident that each series has different capacity to adsorb P. The results of this study showed that the Minkonmingon soil had the highest adsorption maximum with $936.09 \mathrm{mg} \mathrm{kg}^{-1}$ followed by Mekoto and Tyele series with 823.37 and $311.15 \mathrm{mg} \mathrm{kg}^{-1}$, respectively.

The adsorption isotherms of the three soils series had different curves (Figure 1). The curves followed a smooth plateau pattern. It is evident from the curves that the amount of $\mathrm{P}$ adsorption increased with an increase in the concentration of solution $\mathrm{P}$, to point where addition of higher amount of $\mathrm{P}$ does not lead to increases in amount of $\mathrm{P}$ adsorbed.

The adsorption isotherms were used to evaluate the linear form of the five equations. When the sorption data was plotted in the Langmuir equation by taking $\mathrm{C} / \mathrm{X}$ against $\mathrm{C}$ (Figure 3), a good fit was observed. The slope of the plot was less than 0.01 . While the $\mathrm{R}^{2}$ value was highest $(0.99)$ in the Tyele series followed by Mekoto with a $\mathrm{R}^{2}$ value of 0.98 and the Minkonmingon series with value of 0.83 (Table 4). It was observed from the study that the Langmuir equation have a good fit with data at lower concentrations of $\mathrm{P}$. Comparison of the Langmuir adsorption maximum $\left(b_{L}\right)$ for the three soil series showed that values of adsorption maximum, was 1274, 1091 and $333 \mathrm{mg} \mathrm{kg}^{-1}$ for the Minkonmingon, Mekoto and Tyele soils, respectively (Table 1). It was observed that the Langmuir equation gave higher value of maximum adsorbed than the actual values (936. $09,823.37$ and $311.15 \mathrm{mg} \mathrm{kg}^{-1}$ ) respectively for the Minkonmingon, Mekoto and Tyele soils series. The binding energy was highest for Tyele, $0.230 \mathrm{~L}(\mathrm{mg} \mathrm{P})^{-1}$, followed by mekoto with 0.048 and $0.046 \mathrm{~L}$ $(\mathrm{mg} \mathrm{P})^{-1}$ for the Minkonmingon soil series.

The adsorption isotherm examined by the linear form of the Freundlich equation $\mathrm{Y}$ plotting $\log \mathrm{C}$ against $\log \mathrm{X}$ (Figure 4) showed than a good linear fit to the data of the three series was observed. The exponent (b) obtained from the equation was greater than 0.3 with the maximum value of 0.77 observed in the Mekoto series and the lowest was observed in the Tyele series with 0.34. Also, the values observed were high compared to those of the Langmuir equation, with the highest $\mathrm{R}^{2}$ of 0.998 observed in Tyele soil series (Table 4).

The adsorption isotherms of the Van Huay equation are obtained after plotting $\mathrm{X}$ 
against $C^{0.5}$. It was observed that the Van Huay equation show a good fit to the data of the three soil series. The Van Huay coefficient adsorption was high for the Minkonmingon soil series followed by Mekoto and Tyele soils with values of $136.3,115.5$ and $35.64 \mathrm{~L} \mathrm{~kg}^{-1}$ respectively. The data of all the soil series fitted well this equation with $\mathrm{R}^{2}$ values of $0.96,0.97$ and 0.98 respectively. It also indicated that similar to the Freundlich and Langmuir equations, that Van huay equation has a good fit with the data at low concentration of $\mathrm{P}$.

The adsorption isotherm of the Temkin equation was obtained after plotting $\mathrm{X}$ against $\ln \mathrm{C}$ and the linear equation of the adsorption isotherm was obtained after plotting $\mathrm{X}$ against C. It was observed that the Temkin and the linear equations did not show a good fit to the data of the three soil series as compared to the Van Huay, Langmuir and Freundlich equations. The exponent (b) of Temkin was higher in all the three soil series, with the values of $162.70 \mathrm{~mL} \mathrm{~g}^{-1}$ for the Mekoto series followed by the Minkonmingon and Tyele series with values of 138.4 and $32.92 \mathrm{~mL} \mathrm{~g}^{-1}$. The data well fitted the Tyele and Mekoto with the values of 0.90 for the both, while the value of Minkonmingon is 0.70 . Adsorption isotherms of the Linear equation were high for the Minkonmingon and Mekoto soil series gave adsorption constants with the values of 16.08 and 12.98 respectively. The data of the two soil series had a good fit with the values of 0.90 for both soil series, while for Tyele soil series, the value was 0.83 with the value of the adsorption constant of 3.89 .

The relationship between $\mathrm{P}$ adsorption and soil properties indicated that a significant and negative correlation exists between adsorbed $\mathrm{P}$ and Silt, potassium and free aluminum content with $\mathrm{r}$ values of 0.998 , 0.987 and 0.996 respectively, while adsorbed $\mathrm{P}$ had a positive and significant correlation with $\mathrm{pH} \mathrm{KCl}$ with an $\mathrm{r}$ value of 0.987 . There was positive but insignificant correlation between $\mathrm{P}$ adsorbed and exchangeable acidity $(0.843)$ and soil organic carbon $(0.245)$ (Table 6). Adsorbed P negatively correlated with free aluminum suggesting that free aluminum may compete with $\mathrm{P}$ for adsorption sites in agreement with previous findings for others soils (Heredia, 1997; Zhang et al., 2005). In the case of the Minkonmingon, Tyele and Mekoto soil series, as the OM content is low, the free iron and aluminum content increase. The fact that silt influenced $\mathrm{P}$ adsorption maxima in this study is in disagreement with the results of Zhang et al. (2005) who showed that it is clay that mostly influenced the adsorption of P. In contrast to the results of Dodor et al. (2000) and Zhang et al. (2005), soil $\mathrm{pH}$ had a significant relationship with $\mathrm{P}$ adsorption. Exchangeable $\mathrm{K}$ was significantly and negatively correlated with $\mathrm{P}$ adsorption and this contrasts the results of Sims et al. (2002), but is in agreement with the findings of Moazed et al. (2010) who showed that some exchangeable bases can have a significant relationship with $\mathrm{P}$ adsorption. Amount of silt in the soil can be a better index to predict phosphorous adsorption than other soil properties. In acid soils, the amount of free aluminum with the regression equation equals to $99 \%$ can be used to predict phosphorous adsorbed in the soil. The amount of potassium in the soil can also be used to predict phosphorous adsorption in the soils of the study areas. 


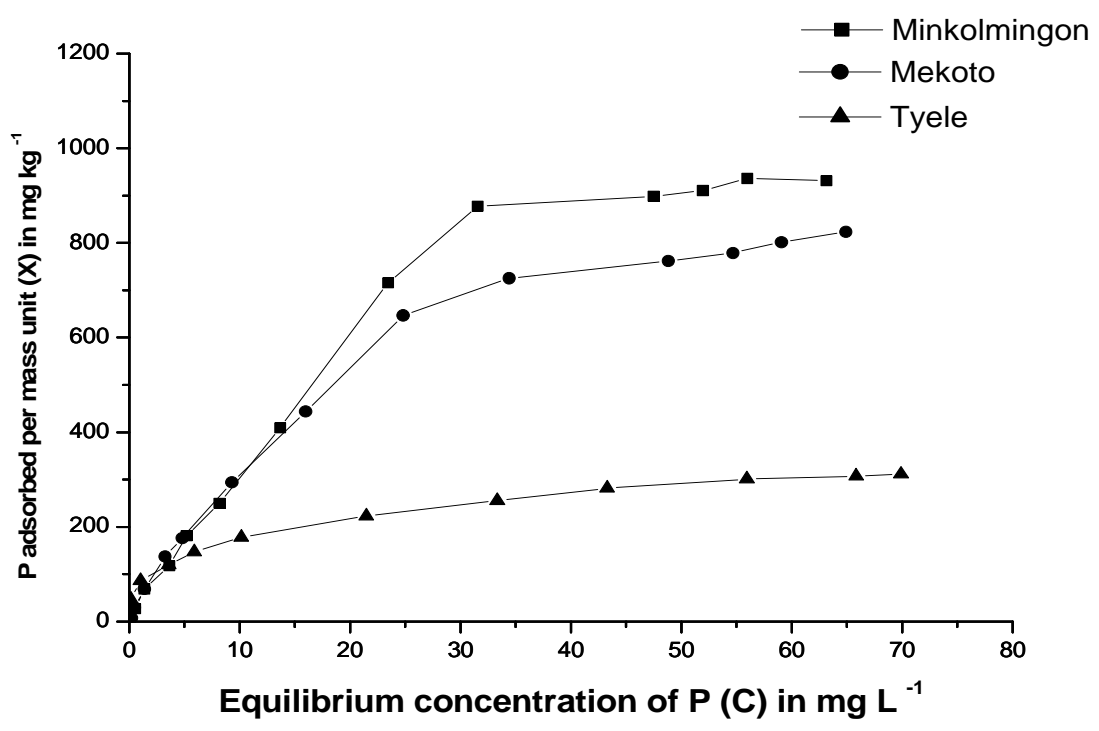

Figure 1: Phosphate adsorption isotherms of soils.

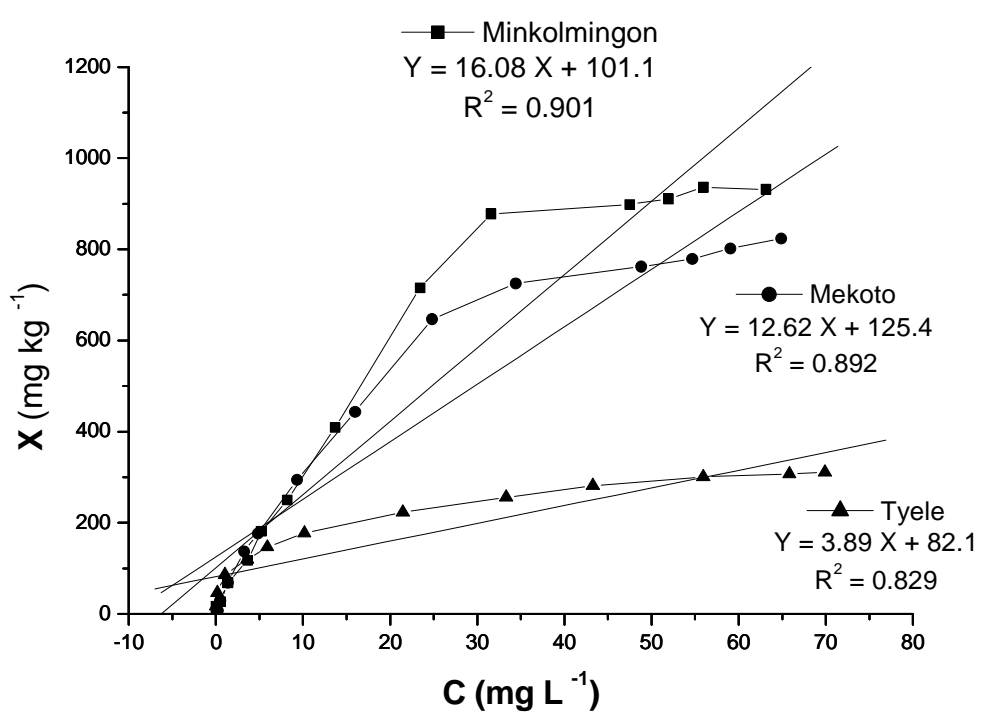

Figure 2: Linear adsorption isotherms of the soils. 


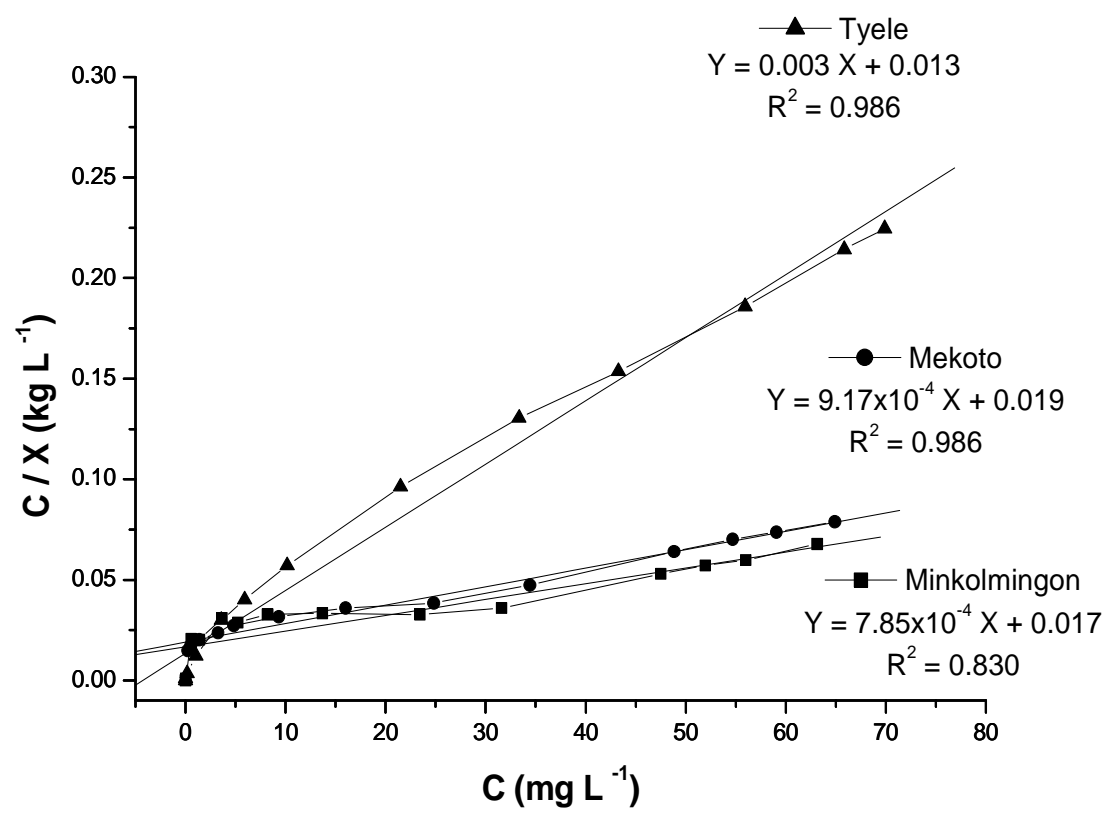

Figure 3: Linear Langmuir adsorption isotherms of the soils.

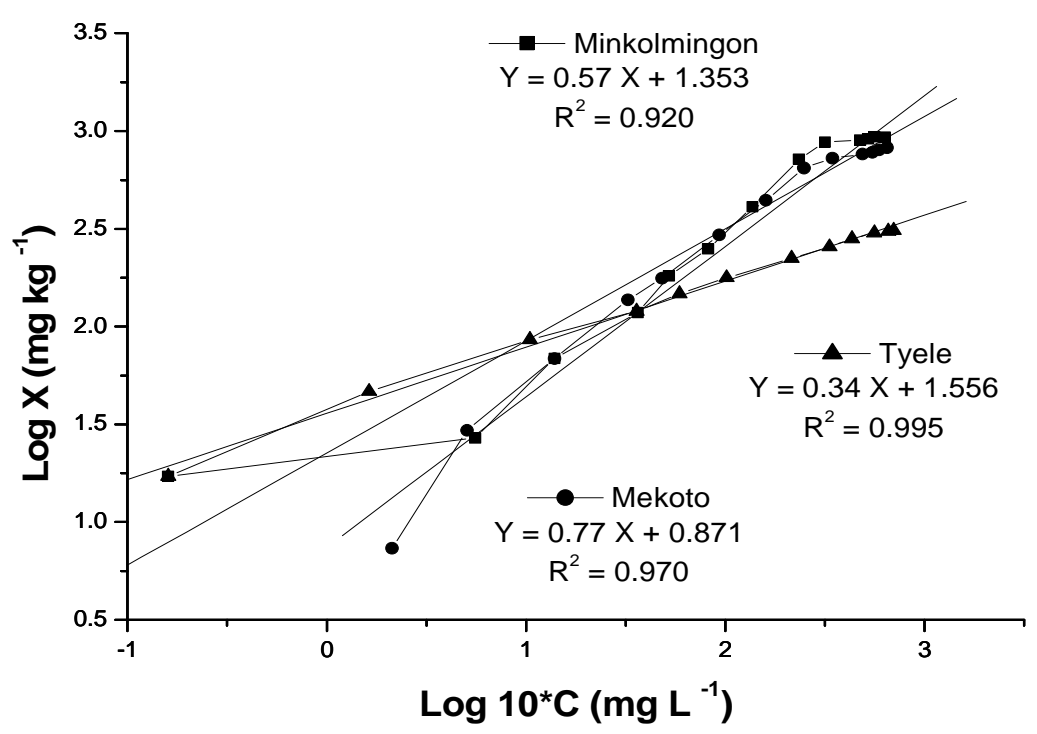

Figure 4: Linear Freundlich adsorption isotherms of the soils. 


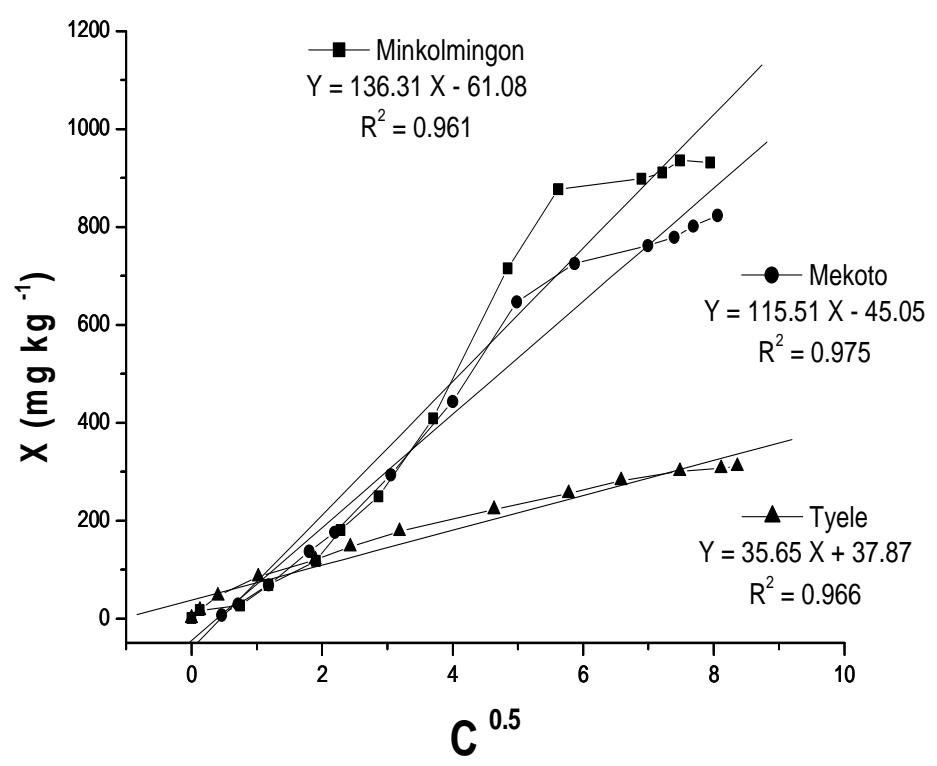

Figure 5: Van Huay adsorption isotherms of the soils.

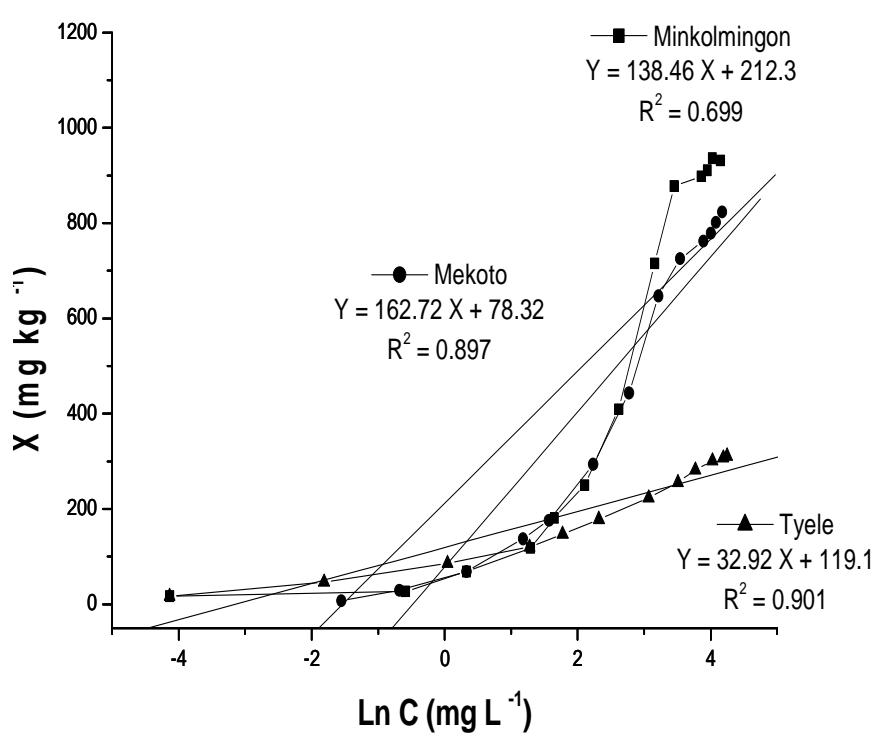

Figure 6: Temkin adsorption isotherms of the soils. 
A. A. ONANA et al. / Int. J. Biol. Chem. Sci. 10(2): 820-834, 2016

Table 1: Selected properties of the $0-20 \mathrm{~cm}$ depth of the soils $(\mathrm{n}=2)$.

\begin{tabular}{|c|c|c|c|c|c|c|c|}
\hline Soil series & pH H20 & pH KCl & $\Delta \mathrm{pH}$ & $\begin{array}{c}\mathrm{SOC} \\
\left(\mathrm{g} \mathrm{kg}^{-1}\right)\end{array}$ & $\begin{array}{c}\text { Clay } \\
\left(\mathrm{g} \mathrm{kg}^{-1}\right)\end{array}$ & $\begin{array}{c}\text { Silt } \\
\left(\mathrm{g} \mathrm{kg}^{-1}\right)\end{array}$ & $\begin{array}{l}\text { Sand } \\
\left(\mathrm{g} \mathrm{kg}^{-1}\right)\end{array}$ \\
\hline Tyele & 5.0 & 4.7 & -0.3 & 22.7 & 350 & 120 & 530 \\
\hline Minkonmingon & 4.2 & 4.0 & -0.4 & 21.9 & 450 & 130 & 430 \\
\hline Mekoto & 5.2 & 4.8 & -0.4 & 19.3 & 380 & 120 & 500 \\
\hline Soil series & $\begin{array}{c}\text { Ca } \\
\left(\mathrm{Cmol}^{2} \mathrm{~kg}^{-1}\right)\end{array}$ & $\begin{array}{c}\mathrm{Mg} \\
\left(\mathrm{Cmol}^{-k^{-1}}\right)\end{array}$ & $\begin{array}{c}\mathrm{K} \\
\left(\mathrm{Cmol}^{-\mathrm{kg}^{-1}}\right)\end{array}$ & $\begin{array}{c}\mathrm{Na} \\
\left(\mathrm{Cmol}^{+} \mathrm{kg}^{-1}\right)\end{array}$ & $\begin{array}{c}\text { Total P } \\
\left(\mathrm{mg} \mathrm{kg}^{-1}\right)\end{array}$ & $\begin{array}{l}\text { Bray 2 P } \\
\left(\mathrm{mg} \mathrm{kg}^{-1}\right)\end{array}$ & \\
\hline Tyele & 0.64 & 0.28 & 0.05 & 0.12 & 893 & 14.37 & \\
\hline Minkonmingon & 0.52 & 0.20 & 0.09 & 0.35 & 1304 & 16.34 & \\
\hline Mekoto & 0.36 & 0.24 & 0.03 & 0.12 & 1161 & 17.46 & \\
\hline Soil series & $\begin{array}{c}\mathrm{AmAl} \\
\left(\mathrm{g} \mathrm{kg}^{-1}\right)\end{array}$ & $\begin{array}{c}\mathrm{AmFe} \\
\left(\mathrm{g} \mathrm{kg}^{-1}\right)\end{array}$ & $\begin{array}{c}\text { FrAl } \\
\left(\mathrm{g} \mathrm{kg}^{-1}\right)\end{array}$ & $\begin{array}{c}\text { FrFe } \\
\left(\mathrm{g} \mathrm{kg}^{-1}\right)\end{array}$ & $\begin{array}{c}\text { CEC } \\
\left({\left.\mathrm{Cmol}+\mathrm{kg}^{-1}\right)}^{-1}\right.\end{array}$ & $\begin{array}{c}\text { EA } \\
\left(\mathrm{mg} \mathrm{kg}^{-1}\right)\end{array}$ & $\begin{array}{c}\mathrm{EC} \\
\left(\mu \mathrm{sm}^{-1}\right)\end{array}$ \\
\hline Tyele & 0.80 & 9.36 & 25.80 & 90.00 & 18.4 & 146.30 & 116.2 \\
\hline Minkonmingon & 2.81 & 8.30 & 35.77 & 46.93 & 16.4 & 255.15 & 104.3 \\
\hline Mekoto & 4.48 & 11.61 & 25.39 & 44.81 & 19.2 & 38.50 & 78.1 \\
\hline
\end{tabular}

Table 2: Values of Van Huay and Langmuir adsorption constants for the soils.

\begin{tabular}{lcccc}
\hline \multirow{2}{*}{ Soil series } & \multicolumn{2}{c}{ Van Huay } & \multicolumn{2}{c}{ Langmuir } \\
\cline { 2 - 5 } & $\mathbf{n}$ & $\mathbf{m}$ & $\mathbf{K}_{\mathbf{L}}$ & $\mathbf{b}_{\mathbf{L}}$ \\
\hline Minkonmingon & 136.3 & -61.08 & 0.046 & 1274 \\
Tyele & 35.64 & 37.86 & 0.230 & 333 \\
Mekoto & 115.5 & -45.05 & 0.048 & 1091 \\
\hline
\end{tabular}

Where $\mathrm{n}=$ Van Huay adsorption coefficient, $\mathrm{m}=$ Van Huay constant parameter,

$\mathrm{b}_{\mathrm{L}}=\mathrm{P}$ adsorption maximum $\left(\mathrm{mg} \mathrm{kg}^{-1}\right)$ and $\mathrm{K}_{\mathrm{L}}=$ constant related to bonding energy

of soil to $\mathrm{P}$ (affinity constant) $\left(\mathrm{L} \mathrm{mg}^{-1} \mathrm{P}\right)$. 
Table 3: Values of Linear, Freundlich and Temkin adsorption constants of the soils.

\begin{tabular}{lccccc}
\hline Soil series & Linear & \multicolumn{2}{c}{ Freundlich } & \multicolumn{2}{c}{ Temkin } \\
\cline { 2 - 6 } & $\mathbf{K}$ & $\mathbf{1 / n}$ & $\mathbf{K f}$ & $\mathbf{b}$ & $\mathbf{a}$ \\
\hline Minkonmingon & 16.08 & 0.57 & 8.43 & 138.40 & 212.30 \\
Tyele & 3.89 & 0.34 & 7.83 & 32.92 & 119.10 \\
Mekoto & 12.98 & 0.77 & 4.37 & 162.70 & 78.32 \\
\hline
\end{tabular}

Where $\mathrm{K}=$ adsorption constant of the solute to the stationary phase surface $\left(\mathrm{mg} \mathrm{kg}^{-1}\right), \mathrm{n}=$ empirical constant related to bonding energy of soil for phosphate, $\mathrm{Kf}=$ Freundlich adsorption constant $\left(\mathrm{mg} \mathrm{kg}^{-1}\right), \mathrm{b}=$ buffer capacity of Temkin model $\left(\mathrm{mL} \mathrm{g}^{-1}\right), \mathrm{b}=$ amount of $\mathrm{P}$ adsorbed $\left(\mathrm{mg} \mathrm{kg}^{-1}\right)$.

Table 4: Regression equations and multiple correlation coefficient x100.

\begin{tabular}{lccc}
\hline Soil series & Model & Equation & $\left(\mathbf{R}^{2}\right) \mathbf{x 1 0 0}$ \\
\hline Minkonmingon & Linear & $\mathrm{Y}=16.08 \mathrm{X}+101.1$ & $90 * * *$ \\
& Langmuir & $\mathrm{Y}=7.85^{*} 10^{-4} \mathrm{X}+0.017$ & $83 * * *$ \\
& Freundlich & $\mathrm{Y}=0.57 \mathrm{X}+1.353$ & $92 * * *$ \\
& Temkin & $\mathrm{Y}=138.4 \mathrm{X}+212.3$ & $70 * * *$ \\
& Van Huay & $\mathrm{Y}=136.3 \mathrm{X}-61.08$ & $96 * * *$ \\
\hline Tyele & Linear & $\mathrm{Y}=3.89 \mathrm{X}+82.05$ & $83 * * *$ \\
& Langmuir & $\mathrm{Y}=0.003 \mathrm{X}+0.013$ & $99 * * *$ \\
& Freundlich & $\mathrm{Y}=0.34 \mathrm{X}+1.556$ & $100 * * *$ \\
& Temkin & $\mathrm{Y}=32.92 \mathrm{X}+119.1$ & $90 * * *$ \\
& Van Huay & $\mathrm{Y}=35.64 \mathrm{X}+37.86$ & $98 * * *$ \\
\hline Mekoto & Linear & $\mathrm{Y}=12.98 \mathrm{X}+107.8$ & $90 * * *$ \\
& Langmuir & $\mathrm{Y}=9.17 * 10-4 \mathrm{X}+0.021$ & $99 * * *$ \\
& Freundlich & $\mathrm{Y}=0.77 \mathrm{X}+0.871$ & $97 * * *$ \\
& Temkin & $\mathrm{Y}=162.7 \mathrm{X}+78.32$ & $90 * * *$ \\
& Van Huay & $\mathrm{Y}=115.5 \mathrm{X}-45.05$ & $97 * * *$ \\
\hline
\end{tabular}

$* * *$ = highly significant.

Table 5: Simple correlation (r) relationships between Langmuir, Freundlich and Van Huay adsorption constants with selected soil characteristics of the soils $(n=6)$.

\begin{tabular}{|c|c|c|c|c|c|}
\hline \multirow[t]{2}{*}{ Soil properties } & \multirow{2}{*}{$\frac{\text { Van Huay }}{n}$} & \multicolumn{2}{|c|}{ Freundlich } & \multicolumn{2}{|c|}{ Langmuir } \\
\hline & & $1 / n$ & Kf & $\mathbf{K}_{\mathbf{L}}$ & $\mathbf{b}_{\mathbf{L}}$ \\
\hline $\mathrm{pH} \mathrm{KCl}$ & $0.952 \mathbf{N S}$ & $0.933 \mathbf{~ N S}$ & $-0.481 \mathrm{NS}$ & $-0.998 *$ & $0.994^{\circ}$ \\
\hline Silt $\left(\mathrm{g} \mathrm{kg}^{-1}\right)$ & $-0.981^{\circ}$ & -0.885 NS & $0.377 \mathbf{N S}$ & $0.999 *$ & $-0.999 * *$ \\
\hline $\mathrm{EA}\left(\mathrm{mg} \mathrm{kg}^{-1}\right)$ & -0.753 NS & $-0.999 *$ & 0.788 NS & $0.892 \mathrm{NS}$ & -0.871 NS \\
\hline $\mathrm{K}\left(\mathrm{cmol} \mathrm{kg}^{-1}\right)$ & $-0.952 \mathbf{N S}$ & -0.932 NS & $0.478 \mathrm{NS}$ & $0.998 *$ & $-0.994^{\circ}$ \\
\hline $\operatorname{FrAl}\left(\mathrm{g} \mathrm{kg}^{-1}\right)$ & $-0.973 \mathbf{N S}$ & $-0.901 \mathbf{~ N S}$ & $0.409 \mathrm{NS}$ & $0.999 * *$ & $-0.999 * *$ \\
\hline $\operatorname{SOC}\left(\mathrm{g} \mathrm{kg}^{-1}\right)$ & $-0.09 \mathrm{NS}$ & $-0.703 \mathbf{~ N S}$ & $0.995 *$ & $0.341 \mathbf{N S}$ & $-0.299 \mathrm{NS}$ \\
\hline
\end{tabular}


Table 6: Pedotransfer functions relating adsorption of $\mathrm{P}(\mathrm{Y})$ to some soil properties of the soils $(n=6)$.

\begin{tabular}{lcc}
\hline Independent variables & Regression equations & $\mathbf{R}^{2}$ \\
\hline $\mathrm{pH} \mathrm{KCl}$ & $\mathrm{Y}=354 \mathrm{pH}-1238$ & $0.974^{\circ}$ \\
Silt $\left(\mathrm{g} \mathrm{kg}^{-1}\right)$ & $\mathrm{Y}=-27.1 \mathrm{Silt}+3692$ & $0.997^{*}$ \\
$\mathrm{EA}\left(\mathrm{mg} \mathrm{kg}^{-1}\right)$ & $\mathrm{Y}=-1.2 \mathrm{EA}+534$ & $0.710 \mathrm{NS}$ \\
$\mathrm{K}\left(\mathrm{Cmol}(+) \mathrm{kg}^{-1}\right)$ & $\mathrm{Y}=-173.6 \mathrm{~K}+505$ & $0.975^{\circ}$ \\
$\mathrm{FrAl}\left(\mathrm{g} \mathrm{kg}^{-1}\right)$ & $\mathrm{Y}=-26.5 \mathrm{Al}+1124$ & $0.993^{*}$ \\
$\mathrm{SOC}\left(\mathrm{g} \mathrm{kg}^{-1}\right)$ & $\mathrm{Y}=-21.7 \mathrm{OC}+817$ & $0.06 \mathrm{NS}$ \\
\hline$* *$ significant at $0.01,{ }^{*}=$ significant at $0.05,{ }^{\circ}=$ significant at $0.1, \mathbf{N S}=$ non significant
\end{tabular}

\section{DISCUSSION}

The lower value of $\mathrm{P}$ adsorption in the Tyele soil series may be due to high amount of exchangeable bases, low value of free and amorphous aluminum content and highest value of organic matter content as reported by Moazed et al. (2010) and Zhang et al. (2005). The higher value of the binding energy constant observed in the Tyele soil series was due to the high content of free iron of the soil $\left(90 \mathrm{~g} \mathrm{~kg}^{-1}\right)$. Olsen and Watanabe (1957) reported 0.92 and $4.39 \mathrm{mg} \mathrm{mg}^{-1}$ in alkaline and acidic soils respectively.

From the above results, we can conclude that the Freundlich model showed a better fit to the data particularly at lower concentrations than the Langmuir, Van Huay, Linear and Temkin models. At higher concentration, the Van Huay model showed a better fit to the data than the Freundlich, Linear, Langmuir and Temkin models. Similar results have been observed for the Freundlich model over the Van Huay, Langmuir and linear models (Dubus and Becquer (2001), and for the Freundlich model over Langmuir and Temkin by other investigators (Moazed et al. 2010). In the Temkin equation, the relationship between amounts of $\mathrm{P}$ adsorbed and the logarithm of the concentrations of $\mathrm{P}$ should give a straight line if the model were suitable for describing adsorption isotherms. However, this was not the case in our study
(Figure 6). The Temkin equation thus has a limited value, despite its potential usefulness over large concentration ranges. These results are in agreement with those of Sanyal et al. (1993) and Dubus and Becquer (2001).

Accuracy of adsorption isotherms for predicting phosphorous adsorption were in decreasing order respectively from Freundlich, single-surface Langmuir isotherm, Van Huay isotherm, Linear adsorption isotherm, and Temkin adsorption isotherm. Standard need of phosphorous calculated through different adsorption isotherms also yielded varied results. As observed in Table 5, there is significant correlation between maximal value of surface-adsorbed phosphorous and soil silt content, $\mathrm{pH} \mathrm{KCl}$, exchangeable potassium and free aluminum. Adsorption Maximum increases with decreasing silt content, exchangeable aluminum and free aluminum while maximal adsorption increases with increasing soil $\mathrm{pH}$ $\mathrm{KCl}$. However, no significant correlation was observed between maximal value of phosphorous adsorption maxima and clay, exchangeable acidity, soil organic carbon, total and available phosphorous and amorphous iron and aluminum. This can be explained by the fact that the soils under are highly weathered and the presence of aluminum reduces P-sorption capacity (Hakim, 2002) due to the direct result of 
competition for sorption sites between phosphate ions and free aluminum. This phenomenon is mainly observed in the case of this study and also with the highest exchangeable bases content of the Tyele soil series. It is also possible that organic matter reduces positively charged surfaces by lowering $\mathrm{pH}$; this decreases the attraction of $\mathrm{P}$ to the soil surface (Hoseini et al., 2013).

\section{Conclusion}

Fitting of different phosphorous adsorption models (Linear, Langmuir, Van Huay, Freundlich and Temkin) showed that all models demonstrate well the relationship between phosphorous in equilibrium solution and adsorbed phosphorous. From the correlation coefficients obtained for all models, Freundlich adsorption isotherm is the most accurate for estimating the amount of phosphorous adsorbed onto soil particle surfaces in different concentrations. The Temkin equation thus has limited value over high and low concentration ranges. Sound knowledge about $\mathrm{P}$ adsorption properties in acid soils under different soils is necessary in sustainable management of soil for crop production. Results of this study revealed differences in $\mathrm{P}$ adsorption and identified soil $\mathrm{pH}$, free aluminum, silt content and exchangeable potassium as main predictors of $P$ activity in the soil under study and that Minkonmingon soil series are mostly affected by $\mathrm{P}$ adsorption followed by Mekoto and Tyele soils. There is need for more intensive sampling and development of multiple regression relationships between $\mathrm{P}$-adsorption and physical, chemical and mineralogical soil properties for more reliable information on soil properties for prediction of $\mathrm{P}$.

\section{COMPETING INTERESTS}

The authors declare that they have no competing interests.

\section{AUTHORS' CONTRIBUTIONS}

AAO described the soils and collected the samples with the guidance of ADMZ and BPY who are his supervisors. They help in the interpretation of adsorption curves. AAO collected the soils samples with the assistance of VA who helped in the field and laboratory work for the physico-chemical analysis of soils.

\section{REFERENCES}

Antonio V, Pigna M. 2002. Competitive sorption of Arsenate and Phosphate on different clay minerals and soils. Soil Sci. Soc. Am. J., 66(6): 1733-1739. DOI: http://dx.doi.org/10.2136/sssaj2002. 1788

Bache BW, Williams EG. 1971. A phosphate sorption index for soils. Soil Sci. Soc. Am. J., 22(3): 289 - 301. DOI: http://dx.doi.org/10.2136/sssaj1971.0361 5995003500060019x

Barrow NJ. 1978. The description of the adsorption of molybdate, sulphate and phosphate by soils. Journal of Soil Science. 109(5): 282-288. DOI: http://dx.doi.org/10.1097/00010694197005000-00004

Bray RH, Kurtz LT. 1945. Determination of total, organic, and available forms of phosphorous in soils. Soil Science., 59(1): $\quad 39 \quad-\quad 45 . \quad$ DOI: http://dx.doi.org/10.1097/00010694194501000-00006

Bunemann EK, Steinebruner F, Smithson PC, Frossard E, Oberson A. 2004b. Phosphorous dynamics in a highly weathered soil as revealed by isotopic labelling techniques. Soil Sci. Soc. Am. J., 68(5): 1645-1655. DOI: http://dx.doi.org/10.2136/sssaj2004.1645

Dodor DE, Oya K. 2000. Phosphorous sorption characteristics of major soils in Okinawa, Japan. Commun. Soil Sci. Plant Anal., 31(3): 277-288. DOI: 
http://dx.doi.org/10.1080/001036200093 70436

Dubus IG. 1997. La Rétention du Phosphore dans les Sols: Principes d'Etude, Modélisation, Mécanismes et Compartiments du sol Impliqués. Documents Scientifiques et Techniques. ORSTOM : Nouvelle Calédonie.

Dubus IG, Becquer T. 2001. Phosphorous sorption end desorption in oxide-rich Ferralsols of New Caledonia. Australian Journal of Soil Research, 39(2): 403414.

DOI:http://dx.doi.org/10.1071/SR00003

Hakim N. 2002. Organic matter for increasing $P$ fertilizer use efficiency of maize in an Ultisols by using ${ }^{32} \mathrm{P}$ technique. Symposium No. 59, paper No. 229. World Congress on Soil Science Bangkok: Thailand, 14-21 August, 2002.

Heredia OS. 1997. Relación entre distintas formas extractables y adsorbidas defósforo con variables edáficas en Grandes Grupos de suelos de la Provincia de Buenos Aires. Magister Scientiae Thesis. Agronomy school, Universidad de Buenos Aires, p.110.

Holford ICR, Wedderburn RMW., and G. E. G. Mattingly. 1974. A Langmuir twosurface equation as a model for phosphate adsorption by soils. Journal of Soil Science, 25(2): 242 - 255. DOI: http://dx.doi.org/10.11111/j.13652389.1974.tb01121.x

Holford, ICR. 1989. Phosphate behavior in soil. Agricultural Science, 2(5):15-21. DOI:http://dx.doi.org/10.1023/A : 1009823600950

Hoseini Y, Taleshmikaiel RD. 2013. Study of Phosphorous adsorption in soil and its relation to soil properties. Int. J. Agric., 3(1): 163-171. DOI: http://dx.doi.org/ 10.11648/jaff.20140301.18

Kinniburgh DG. 1985. ISOTHERM. A computer program for analyzing adsorption data. Report WD/ST/85/02. Version 2.2. British Geological Survey, Wallinford, England.

Kuo S. 1996. Phosphorous. In Methods of Soil Analysis, Sparks DL (ed) Part 3. Chemical Methods. SSSA Book Series No. 5. Soil Science Society of America and American Society of Agronomy: Madison, Wisconsin: USA; 869-919.

Maria C, and Sims PJT. 2000. Relationship between soil test phosphorous, soluble phosphorous and phosphorous saturation in Delaware soils. Soil .Sci .Soc .Am J., 64(2): 765-773. DOI: http://dx.doi.org/ 10.2136/sssaj2000. 642765x

Moazed H, Hoseini Y, Naseri AA, Abbasi F. 2010. Determining phosphorous adsorption isotherm in soil and its relation to soil characteristics. International Journal of Soil Science, 5(3): 131-139. DOI: http://dx.doi.org/ 10.3923/ijss.2010. 131.139

Niang A I, Amadalo BA, de Wolf J, Gathumbi DM. 2002. Specials screening for short-term planted fallows in the highlands of Western Kenya. Agrofor. Syst., 56(2): 145-154. DOI: http:// dx.doi.org/10.1023/A:1021366911279

Olsen SR, Watanabe FS. 1957. A method to determine a phosphorous adsorption maximum of soils as measured by the Langmuir isotherms. Soil. Sci .Soc .Am J., 21(2): 144-149. DOI: http:// dx.doi.org/10.2136/sssaj1957. $03615995002100020004 x$

Onweremadu EU. 2007. Predicting phosphorous sorption characteristics in highly weathered soils of South-Eastern Nigeria. Res. J. Environ. Sci., 1(2):4755. DOI: http://dx.doi.org/ 10.3923/rjes.2007.47.55

Pauwels JM, van Ranst E, Verloo M, Mvondo Ze AD. 1992. Manuel de Laboratoire de Pédologie. Publications Agricoles $\mathrm{N}^{\circ}$ 28 : Bruxelles. 
R Development Core Team. 2007. R: A language and environment for statistical computing. R Foundation for Statistical Computing, Vienna, Austria. URL http://www.R-project.org.

Rao AS. 1993. Analysis of soils for available major nutrients. In Method of Analysis of Soils, Plants, Water and Fertilizers, Tandon S (ed). Fertilizer Development and Consultation Organization: New Delhi, India; 13-35

Saleque MA, Abedin MJ, Panaullah GM, Bhuyian NI. 1998. Yield and phosphorous efficiency of some lowland rice varieties at different levels of soil available phosphorous. Commun. Soil Sci Plant Anal., 29(19): 2905-2916. DOI:http://dx.doi.org/10.1080/00103629 809370164

Saleque MA, Naher UA, Islan A, Pathan ABMU, Hossain ATMS, Meisner CA. 2004. Inorganic and organic phosphorous fertilizer effects on the phosphorous fractionation in wetland rice soils. Soil Sci. Soc. Am. J., 68(5): 1635 - $\quad 1644 . \quad$ DOI: http://dx.doi.org/10.2136/sssaj2004. 1635

Sanyal SK, Datta SK, Chan PY. 1993. Phosphate sorption-desorption in some acidic soils of south and south-east Asia. Soil Sci. Soc. Am. J., 57(4): 937-945.
DOI:http://dx.doi.org/10.2136/sssaj1993. 03615995005700040011x

Sims JT, Simard RR, Joern BC. 1998. Phosphorous loss in agricultural drainage: historical perspective and current research. J. Environ. Qual., 27(2): 38-45. DOI: http://dx.doi.org/10. $2134 /$ jeq 1998. 004472425002700020006x

Temkin MI, Pyzhev V. 1940. Kinetics for ammonia synthesis on promoted iron catalysts. Acta Physiochim., 12: 327 356. URL: http://en.m.zikipedia. org/wiki/Temkin_equation

Walkley A, Black IA. 1934. An examination of the Degtjareff method for determining soil organic matter and a proposed modification of the chromic acid titration method. Soil Science, 37(1): 2938. DOI: http://dx.doi.org/10. 1097/00010694-193401000-00003

Wild A. 1988. Plant nutrients in soil: phosphate. In Russell's Soil Conditions and Plant Growth $\left(11^{\text {th }}\right.$ edn). Longman Group: UK.

Zhang H, Schroder JL, Fuhrman JK, Basta NT, Storm DE, Patron ME. 2005. Path and multiple regression analysis of phosphorous sorption capacity. Soil Sci. Soc. Am. J., 69(1): 96-106. DOI:http://dx.doi.org/10.2136/sssaj2005. 0096 